\title{
Cognitive, functional and physical activity impairment in elderly with Alzheimer's disease
}

\author{
Renata Valle Pedroso ${ }^{1}$, Danilla Icassatti Corazza², Carla Andreza de Almeida Andreatto³, \\ Thays Martins Vital da Silva ${ }^{4}$, José Luiz Riani Costa ${ }^{1}$, Ruth Ferreira Santos-Galduróz ${ }^{5}$
}

\begin{abstract}
Alzheimer's Disease (AD) is a progressive degenerative disorder that negatively affects quality of life of patients and family members. Objective: The aim of this study is to compare the cognition, level of physical activity and functioning of elderly individuals with mild $A D$ and those without dementia. Methods: The study comprised 24 elderly with mild $\mathrm{AD}$ (mean age $=76.9 \pm 5.3$ years) and 30 elderly without dementia (mean age $=74.1 \pm 5.6$ years). The following instruments were applied to evaluate cognitive functions: MMSE; Frontal Assessment Battery; Clock Drawing Test; Corsi Blocks, and Verbal Paired Associates. Event-related potential P300 was used to evaluate cognitive processing. The Modified Baecke Questionnaire For Older Adults was applied to evaluate the level of physical activity together with use of a pedometer for 7 consecutive days. For the evaluation of the functioning, the Direct Assessment of Functional Status-Revised scale and functional tests were used. Results: There was a significant difference between the groups in level of physical activity and functioning, except on the test evaluating flexibility. Conclusion: Elderly with AD had cognitive, functional and physical activity deficits which can manifest even in the early stages of the disease.
\end{abstract}

Key words: dementia, cognition, functioning, exercise, motor activity.

\section{COMPROMETIMENTO COGNITIVO, FUNCIONAL E DE NÍVEL DE ATIVIDADE FÍSICA DE IDOSOS COM DOENÇA DE ALZHEIMER: PREJUÍZOS NA DOENÇA DE ALZHEIMER}

RESUMO: A doença de Alzheimer é um processo neurodegenerativo e progressivo que afeta, negativamente, a qualidade de vida do paciente e de seus familiares. Objetivo: Comparar a cognição, nível de atividade física capacidade funcional de idosos no estágio leve da doença de Alzheimer e de idosos sem demência. Métodos: Participaram deste estudo 24 idosos no estágio leve da doença de Alzheimer (média de idade =76,9 \pm 5.3 anos) e 30 idosos sem demência (média de idade $=74,1 \pm 5,6$ anos). Foram utilizados os seguintes instrumentos de avaliação cognitiva: MEEM, Bateria de Avaliação Frontal, Teste do Desenho do Relógio, Blocos de Corsi e Pares Verbais Associados. Além disso, foi realizado o exame eletroencefalográfico P300 para avaliar o tempo de processamento de informação. Para quantificar o nível de atividade física foi utilizado o Questionário Baecke Modificado para Idosos e o pedômetro, que foi utilizado por 7 dias consecutivos. A funcionalidade foi avaliada através da escala Direct Assessment of Functional Status-Revised, juntamente com testes funcionais que avaliaram os componentes da capacidade funcional. Resultados: Foram encontradas diferenças significativas entre os grupos para o nível de atividade física e funcionalidade motora, com exceção da avaliação da flexibilidade. Conclusão: Idosos com doença de Alzheimer apresentam prejuízos cognitivos, funcionais e de nível de atividade física, os quais encontram-se alterados nos estágios iniciais da doença.

Palavras-chave: demência, cognição, funcionalidade, exercício, atividade motora.

\footnotetext{
This study was conducted at Institute of Biosciences, Department of Physical Education, UNESP - University State of São Paulo, Physical Activity and Aging Lab (LAFE), Rio Claro, São Paulo, Brazil.

'PhD. Institute of Biosciences, Department of Physical Education, UNESP - University State of São Paulo, Physical Activity and Aging Lab (LAFE), Rio Claro, São Paulo, Brazil; ${ }^{2 P h D}$. Department of Physical Education, State University of Ponta Grossa - UEPG, Ponta Grossa, Paraná, Brazil; ${ }^{3} \mathrm{Ms}$. Institute of Biosciences, Department of Physical Education, UNESP - University State of São Paulo, Physical Activity and Aging Lab (LAFE), Rio Claro, São Paulo, Brazil; 4PhD. Instituto Federal Goiano (IF Goiano) - Campus Morrinhos, Goiás, Brazil; ${ }^{5}$ PhD. Institute of Biosciences, Department of Physical Education, UNESP - University State of São Paulo, Physical Activity and Aging Lab (LAFE), Rio Claro, São Paulo, Brazil. Center of Mathematics, Computing and Cognition, University Federal of ABC - UFABC, Santo André, São Paulo, Brazil.
}

Renata Valle Pedroso. Av. 24A, no. 1515 - 13506-900 Rio Claro SP - Brazil. E-mail: re.pedroso@hotmail.com

Disclosure: The authors report no conflicts of interest.

Received July 19, 2017. Accepted in final form October 31, 2017

(cc) BY 
$\mathrm{T}$ he progression of Alzheimer's disease (AD) is characterized by neuronal degeneration that results in a gradual decline in numerous cognitive processes and cortical activity. ${ }^{1}$ In addition to these cognitive impairments, as the disease progresses $\mathrm{AD}$ patients can develop impairments to motor skills including reduced levels of flexibility, agility, strength, balance and aerobic resistance. ${ }^{2-5}$ Such impairments can directly affect the elderly's ability to perform activities of daily living (ADLs). ${ }^{6}$ ADLs require integrity not only of cognitive components, but also of the motor components of functional capacity (flexibility, resistance, strength, agility, balance, rhythm, motor coordination and speed) in order to be carried out effectively and safely. ${ }^{6}$

Therefore, the cognitive and functional deficits of $\mathrm{AD}$ progression are an important issue since, as they are strongly associated with ADLs, their impairment can entail reduced autonomy followed by increased risk of institutionalization; death; depression and decreased level of physical activity. ${ }^{1,4}$ Some studies have found that elderly with $\mathrm{AD}$ exhibit a low level of physical activity but have not specifically investigated individuals in the mild stage of $\mathrm{AD} .^{4,7}$ Given this perspective, it is important to investigate which impairments might be present in the early stages of AD. Hence, the objective of this study was to compare cognition, level of physical activity and functioning between elderly individuals in the early stage of $\mathrm{AD}$ with elderly individuals without dementia.

\section{METHODS \\ Subjects}

The sample comprised 30 elderly without dementia and 24 elderly with a clinical diagnosis of probable
AD. Subjects were recruited from the Functional and Cognitive Kinesiotherapy Program in Older Adults with Alzheimer's Disease (PRO-CDA) and from the Program of Physical Activity for Senior Citizens (PROFIT), offered by the Department of Physical Education of the Institute of Biosciences at the Universidade Estadual Paulista "Julio de Mesquita Filho" (UNESP), Rio Claro campus.

The inclusion criteria for the elderly without dementia were: age between 65 and 90 years; no clinically relevant depressive symptoms and/or untreated symptoms; no diagnosis of $\mathrm{AD}$; preserved ambulation; no hearing impairment; and no other neuropsychiatric conditions. The inclusion criteria for the elderly with $\mathrm{AD}$ were: diagnosis of probable AD according to the Diagnostic and Statistical Manual of Mental Disorders (DSM-IV), ${ }^{8}$ and elderly with $\mathrm{AD}$ in the mild stage of the disease according to the Clinical Dementia Rating (CDR).,10

Table 1 shows the general characteristics of the group without dementia and the group with $\mathrm{AD}$ that participated in the study.

The elderly without dementia, and the caregivers of these elderly with AD, signed an Informed Consent Form. The Research Ethics Committee of the Universidade Estadual Paulista approved both the consent form and the research Project under protocol number 3174.

\section{Data collection}

A psychiatrist specialized in geriatrics evaluated the participants on their first visit to the laboratory in order to confirm the diagnosis and staging of $\mathrm{AD}$. The first sessions were then scheduled for evaluations of cognitive performance and level of physical activity followed by application of the functional tests.

Table 1. Means and standard deviations of general characteristics and cognitive evaluation of the group without dementia and the group with AD.

\begin{tabular}{lcccc}
\hline & Elderly without dementia $(\mathbf{N}=\mathbf{3 0})$ & Alzheimer's disease $(\mathbf{N}=\mathbf{2 4})$ & $\mathbf{P}$ & Effect size (d) \\
\hline Age (years) & $74.1 \pm 5.6$ & $76.9 \pm 5.3$ & 0.06 & - \\
\hline Education level (years) & $4.5 \pm 3.7$ & $5.0 \pm 4.1$ & 0.66 & - \\
\hline MMSE (points) & $24.6 \pm 4.0$ & $19.8 \pm 4.5$ & $<0.01^{*}$ & 1.12 \\
\hline FAB & $13.5 \pm 2.9$ & $10.5 \pm 3.7$ & $0.04^{*}$ & 0.38 \\
\hline GDS-30 (points) & $6.9 \pm 5.4$ & $5.9 \pm 4.6$ & 0.54 & - \\
\hline Height (meters) & $1.53 \pm 0.05$ & $1.57 \pm 0.07$ & $0.03^{*}$ & 0.16 \\
\hline Weight $(\mathrm{Kg})$ & $62.7 \pm 10.3$ & $63.9 \pm 9.9$ & 0.68 & - \\
\hline BMl $\left(\mathrm{Kg} / \mathrm{m}^{2}\right)$ & $26.5 \pm 4.0$ & $25.9 \pm 3.5$ & 0.55 & - \\
\hline
\end{tabular}

MMSE: Mini-Mental State Examination, FAB: Frontal Assessment Battery, GDS-30: Geriatric Depression Scale, Kg: Kilograms, BMI: Body Mass Index; * ${ }^{*} \leq 0.05$. Student's t-test. 


\section{Evaluation instruments}

\section{Cognitive evaluation and depressive symptoms}

The Mini-Mental State Examination was used to evaluate overall cognitive function. ${ }^{11,12}$ The Frontal Assessment Battery was used for the evaluation of participants' frontal functions (executive and attention). ${ }^{13,14}$

Cognitive processing speed was evaluated by the auditory event-related potential P300. For this purpose, the oddball paradigm was adopted using a device for the electrophysiological auditory evaluation (CONTRONIC, model "MASBE ATC Plus").

The reference electrodes were placed on the right and left mastoid, and the electrode for recording P300 was placed on the vertex, at a high mid-frontal position (position Fz), according to the 10-2 international system. We applied a sequence of binaural auditory stimuli, containing two signals of the same intensity (90 dB). Within the sequence, the standard stimulus $(1000 \mathrm{~Hz})$ was presented $80 \%$ of the time, while the rare stimulus (2000 Hz) was randomly interposed between standard stimuli $20 \%$ of the time. A total of 300 stimuli were emitted, each of lasting $100 \mathrm{~ms}$.

The Geriatric Depression Scale (GDS-30) was applied to evaluate depressive symptoms. ${ }^{15}$

\section{Evaluation of level of physical activity}

The level of physical activity was assessed by the Modified Baecke Questionnaire for Older Adults (MBQ) ${ }^{16}$ and a Yamax Digiwalker pedometer for seven consecutive days.

\section{Evaluation of functioning}

Functioning was assessed using the Direct Assessment of Functional Status (DAFS-R) instrument. ${ }^{17}$ Several functional tests were applied: 6-minute Walk Test ${ }^{18}$ to assess aerobic resistance, 30-s Chair-Stand Test ${ }^{17}$ and Arm Curl Test (AAHPERD) ${ }^{19}$ to assess strength resistance of the lower and upper limbs, respectively, Berg Functional Balance Scale (BFBS) ${ }^{20}$ to evaluate static and dynamic balance and balance recovery, the Timed Up-and-Go test (TUG) ${ }^{21}$ to evaluate basic functional mobility, and finally the Wells Sit-and-Reach Test ${ }^{22}$ to evaluate flexibility.

\section{Statistical analysis}

The Shapiro Wilk test was initially used to analyze data distribution. Student's $t$ - test was used for data displaying a normal distribution. For the groups that had a non-normal distribution, the Mann Whitney's $\mathrm{U}$ test was employed. The level of significance was set

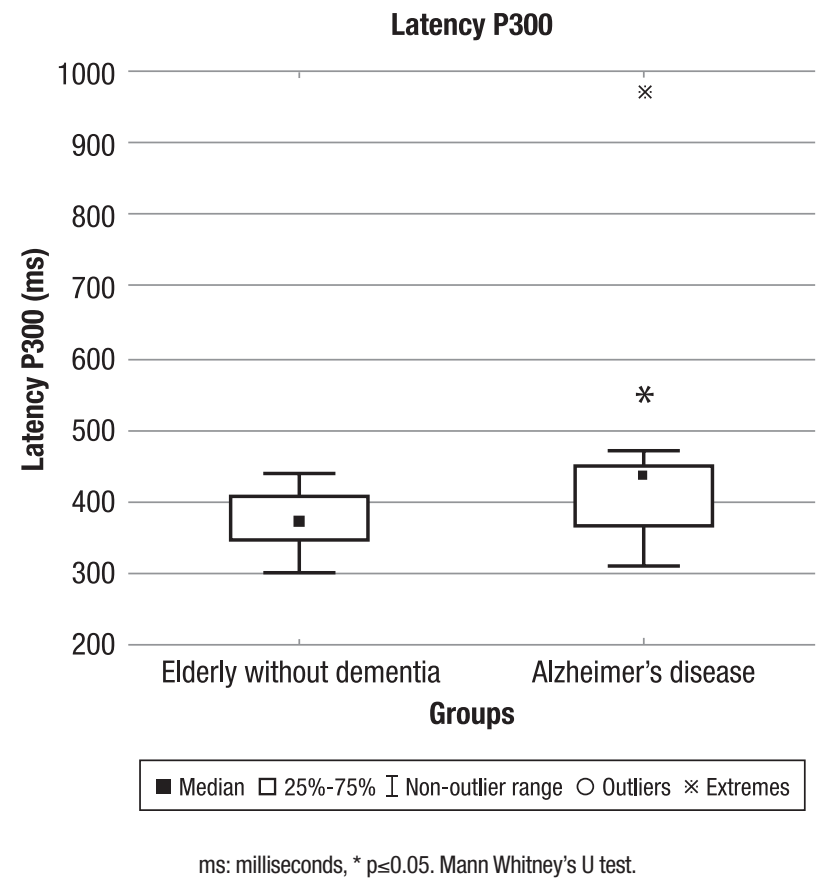

Figure 1. Median and interquartile range of P300 (ms) latency of the group without dementia and the group with $\mathrm{AD}$.

at $5 \%$ for all analyses. All data were expressed descriptively. The statistical software Statistica version 7.0 was used for all data analyses.

\section{RESULTS}

\section{Cognitive functions}

The elderly with mild AD exhibited impairment of cognitive and frontal functions when compared with the individuals without dementia (Table 1). Additionally, the P300 evaluation showed that the group with $\mathrm{AD}$ had longer latency, indicating slower cognitive processing than the group without dementia $(\mathrm{p}=0.01)$ (Figure 1).

\section{Level of physical activity}

According to both evaluation instruments, the elderly with mild $\mathrm{AD}$ had lower levels of physical activity (Table 2). Moreover, the analysis of the MBQ showed that the groups differed mainly for performance of household chores (Table 2).

\section{Functional tests}

The elderly with AD had higher deterioration of strength resistance of lower and upper limbs and worse balance, agility/mobility and aerobic resistance than the elderly without dementia. No significant differences were detected between the groups for flexibility (Table 2). 
Table 2. Means and standard deviations/median and interquartile range of functional tests and level of physical activity of the group without dementia and the group with AD.

\begin{tabular}{|c|c|c|c|c|c|c|}
\hline & \multicolumn{2}{|c|}{ Elderly without dementia $(\mathrm{N}=30)$} & \multicolumn{2}{|c|}{ Alzheimer's disease $(\mathrm{N}=24)$} & \multirow[b]{2}{*}{$\mathbf{P}$} & \multirow[b]{2}{*}{$\begin{array}{l}\text { Effect } \\
\text { size (d) }\end{array}$} \\
\hline & $\begin{array}{l}\text { Mean } \pm \text { standard } \\
\text { deviations }\end{array}$ & $\begin{array}{l}\text { Median/Interquartile } \\
\text { range }\end{array}$ & $\begin{array}{l}\text { Mean } \pm \text { standard } \\
\text { deviations }\end{array}$ & $\begin{array}{l}\text { Median/Interquartile } \\
\text { range }\end{array}$ & & \\
\hline 30-s Chair-Stand Test & - & $14.5 / 12.0-19.0$ & 一 & 11.0/9.0-13.5 & $<0.01^{*}$ & 1.10 \\
\hline Arm Curl Test & - & 21.0/18.0-29.0 & - & $17.0 / 13.0-21.0$ & $<0.01^{*}$ & 1.74 \\
\hline Wells Test & - & 22.0/18.0-28.0 & - & 20.0/13.0-25.5 & 0.17 & - \\
\hline TUG Time & $7.3 \pm 1.8$ & - & $8.6 \pm 1.9$ & - & $<0.01^{*}$ & 0.70 \\
\hline TUG Steps & - & $54.0 / 52.0-56.0$ & - & $16.0 / 14.0-88.0$ & $<0.27$ & - \\
\hline BFBS (points) & - & $54.0 / 52.0-56.0$ & - & $52.0 / 50.0-54.0$ & $0.04^{*}$ & 0.43 \\
\hline MBQ Household Chores & - & 2.0/1.6-2.4 & - & $1.2 / 0.8-1.8$ & $<0.01^{*}$ & 1.37 \\
\hline MBQ Sports Activities & - & $0.0 / 0.0-2.2$ & - & $0.0 / 0.0-0.0$ & 0.07 & - \\
\hline MBQ Leisure & - & $0.5 / 0.0-1.2$ & - & $0.0 / 0.0-1.4$ & 0.41 & - \\
\hline MBQ Total Score & - & $3.0 / 2.4-5.5$ & - & $1.9 / 1.0-4.3$ & $<0.01^{*}$ & 0.72 \\
\hline Pedometer (steps) & - & $6154 / 4317-8556$ & - & $1509 / 605-4411$ & $<0.01^{*}$ & 0.93 \\
\hline
\end{tabular}

TUG: Timed Up-and-Go; BFBS: Berg Functional Balance Scale; MBQ: Modified Baecke Questionnaire for Older Adults. ${ }^{\star} \mathrm{p} \leq 0.05$. Student's t-test for TUG time and Mann Whitney's U test for the other items.

Table 3. Means and standard deviations/median and interquartile range on the Direct Assessment of Functional Status (DAFS) of the group without dementia and the group with $A D$.

\begin{tabular}{|c|c|c|c|c|c|c|}
\hline & \multicolumn{2}{|c|}{ Elderly without dementia $(\mathrm{N}=30)$} & \multicolumn{2}{|c|}{ Alzheimer's disease $(\mathrm{N}=24)$} & \multirow[b]{2}{*}{$\mathbf{P}$} & \multirow[b]{2}{*}{$\begin{array}{l}\text { Effect } \\
\text { size (d) }\end{array}$} \\
\hline & $\begin{array}{c}\text { Mean } \pm \text { standard } \\
\text { deviations }\end{array}$ & $\begin{array}{l}\text { Median/Interquartile } \\
\text { range }\end{array}$ & $\begin{array}{l}\text { Mean } \pm \text { standard } \\
\text { deviations }\end{array}$ & $\begin{array}{l}\text { Median/Interquartile } \\
\text { range }\end{array}$ & & \\
\hline DAFS Time Orientation & - & $16.0 / 14.0-16.0$ & - & $12.0 / 9.0-14.0$ & $<0.01^{*}$ & 1.35 \\
\hline DAFS Communication & - & $14.0 / 12.0-15.0$ & - & $10.0 / 7.0-13.0$ & $<0.01^{*}$ & 0.94 \\
\hline DAFS Finance & $20.5 \pm 8.2$ & - & $13.6 \pm 5.9$ & - & $0.01^{*}$ & 0.96 \\
\hline DAFS Shopping & - & $14.0 / 13.0-17.0$ & - & $8.0 / 2.0-15.0$ & $<0.01^{*}$ & 1.20 \\
\hline DAFS Grooming & - & $13.0 / 13.0-13.0$ & 一 & $11.5 / 10.0-13.0$ & $<0.01^{*}$ & 1.41 \\
\hline DAFS Eating & - & $10.0 / 10.0-10.0$ & - & $10.0 / 10.0-10.0$ & 0.60 & ------ \\
\hline DAFS Total Score & - & $85.5 / 73.0-97.0$ & - & $62.5 / 55.0-72.0$ & $<0.01^{*}$ & 1.53 \\
\hline
\end{tabular}

DAFS: Direct Assessment of Functional Status. * $p \leq 0.05$. Student's $t$ - test for DAFS finance and Mann Whitney's $U$ test for the other items.

\section{Functioning}

The elderly with $\mathrm{AD}$ showed greater deterioration of functioning when compared with the elderly without dementia (Table 3). The groups differed on the subitems time orientation, communication, finance, shopping and grooming. There were no differences for the sub-item eating (Table 3).

\section{DISCUSSION}

\section{Cognitive functions}

The interpretation of the data found in this study revealed that the elderly with $\mathrm{AD}$ in the mild stage of the disease had greater deterioration in global cognitive functions and also frontal functions when compared with the elderly without dementia, where these results agree with other studies. ${ }^{23}$ 
The latency of P300 was analyzed in both groups using an electroencephalographic exam to identify possible differences in cognitive processing speed. The elderly with AD had longer P300 latency (416 ms) than the elderly without dementia (375 ms). In their review study, Pedroso et al..$^{24}$ analyzed several studies that also made this comparison. However, few of them evaluated only elderly in the early stage of AD. Pedroso et al. ${ }^{24}$ found $\mathrm{P} 300$ values in the $358 \mathrm{~ms}-458 \mathrm{~ms}$ range. The results of the present study were also within this range, showing cognitive processing delay among the elderly in the mild stage of the disease.

\section{Level of physical activity}

The level of physical activity of the elderly with mild AD was lower than that of the elderly without dementia, both according to the MBQ and the pedometer, findings that corroborate results reported in the literature., ${ }^{4,25}$

Lima et al. ${ }^{7}$ used a pedometer to evaluate the level of physical activity of patients with $\mathrm{AD}$, and found low levels (4400 steps). Moreover, the authors suggested that 6000-6500 steps a day would be the recommended number for this specific group. The elderly with $\mathrm{AD}$ performed a median of only 1509 steps/day. The elderly without dementia had a median of 6154 steps/day, within the expected range according to Tudor-Locke et al. ${ }^{26}$

The MBQ results also showed that the elderly with $\mathrm{AD}$ had a low level of physical activity (median of 1.9 points on the test). This result is in line with those of other studies in the literature that detected a mean of 2.59 points $^{4}$ and 1.8 points. ${ }^{27}$ None of these studies, however, evaluated the level of physical activity of elderly individuals specifically in the mild stage of $\mathrm{AD}$.

The analysis of MBQ domains revealed that the elderly with $\mathrm{AD}$ had lower performance for household chores in the very early stages of $\mathrm{AD}$. This reduction may be associated with the cognitive impairment resulting from the condition.

\section{Functional tests}

Elderly with mild $\mathrm{AD}$ showed lower strength resistance of lower limbs. Eggermont et al. ${ }^{5}$ observed no differences between groups, whereas Manckoundia et al. ${ }^{2}$ found that the elderly with $\mathrm{AD}$ in the mild and moderate stages of the disease had poorer performance on the sitto-stand and back-to-sit test.

The elderly with $\mathrm{AD}$ also showed impaired resistance of the upper limbs. The finding of altered lower and upper limb resistance is fundamental, since this muscle function is highly recruited in the performance of daily living activities ${ }^{28,29}$ and therefore directly affects the autonomy of the individual with dementia.

The only component of functional capacity that did not show significant difference between groups was flexibility. We found no studies in the literature comparing flexibility between elderly with and without AD. One of the explanations could be related to the test, which may not have been sensitive to detect few differences between groups. Another reason might be that flexibility suffers little influence from the cognitive declines of $\mathrm{AD}$.

The elderly in the early stage of $\mathrm{AD}$ had impaired functional balance, with a median of 52 points on the BFBS versus 54 points in the elderly without $\mathrm{AD}$. Pedroso et al..$^{30}$ detected a mean of 49 points on the BFBS. The participants of the study, however, were in the early and mild stages of the disease. Kato-Narita et al. ${ }^{3}$ found greater balance deterioration (also evaluated by the BFBS) in elderly in the moderate stage of $A D$ compared with elderly without AD. Our study found evidence that this deterioration might already be present in the early stage of AD.

According to the evaluation of agility and mobility by the TUG test, elderly with $\mathrm{AD}$ performed the test in 8.6 seconds. Coelho et al., ${ }^{31}$ in a recent study comparing elderly with $\mathrm{AD}$ in several stages of the disease, found that those in the mild stage performed the test in 9.2 seconds. Some studies have shown that elderly with $\mathrm{AD}$ have greater mobility/agility impairment than those without dementia., ${ }^{4}$

Rikli and Jones ${ }^{28}$ reported that elderly with $\mathrm{AD}$ are already within the range of impairment of functional independence, since 8.5 seconds on the test is the cutoff point identified as a predictor of falls among the older elderly, which occur at a rate of 4 to 5 falls per year. ${ }^{32}$

Finally, the last component of the functional capacity evaluated was aerobic resistance. The group with $\mathrm{AD}$ had poorer performance (406 meters) than the group without dementia (443 meters) on the 6-minute Walk Test. This result corroborates data in the literature, according to which elderly with dementia have reduced cardiorespiratory capacity. ${ }^{33}$ Rikli and Jones ${ }^{28}$ suggested a cut-off point on the 6-minute Walk Test for elderly aged over 85 years of 400 to 460 meters in order to be considered independent.

\section{Functioning}

The elderly with $\mathrm{AD}$ had a median score of 62.5 , lower than that of the group without dementia (85.5 points), suggesting impaired functioning and decreased ADLs in the elderly with AD. Zanetti et al. ${ }^{34}$ also found differ- 
ences between elderly with and without AD. However, the authors evaluated elderly at different stages of the disease in the same sample.

Several studies have suggested that this decrease in ADLs is associated not only with cognitive decline, but also with functional decline and behavioral disorders present during the progression of $\mathrm{AD} .{ }^{35}$

The AD group in the present study showed impairment for time orientation, communication, finance, shopping and grooming. The only variable evaluated that did not differ between the groups was eating.

The final score of the elderly in the mild stage of $\mathrm{AD}$ in the cited study was similar to the score found in the present study (58 points). The authors, however, did not investigate for which activities the elderly were impairment. Consequently, we can infer that eating may have been preserved in the early stages of $\mathrm{AD}$. In fact, the first ADL altered in elderly with dementia is time orientation, followed by more complex tasks that require preserved cognitive functions, such as finance and shopping. ${ }^{16}$ The evaluation of functioning by the DAFS is important to assess the elderly with or without dementia for performance of ADLs.

The authors of the present study acknowledge several limitations that should be considered when interpreting the data. One of these limitations is related to the small sample size and the lack of sample size estimation. In addition, the assessment of the level of physical activity had some limitations. For instance, pedometers are unable to measure the intensity of physical activity. However, the questionnaires applied are subjective and the caregiver answers the questions about the patient. Based on the interpretation of the results obtained in the present study, it can concluded that the elderly with $\mathrm{AD}$ exhibited cognitive and functional impairment, and reduced physical activity, which can be present even in the early stages of the disease. The relevance of the present study is that it can help support the creation of intervention programs targeting the population with Alzheimer's disease, since these elderly individuals have specific needs, as highlighted by this study.

Author contribution. Renata Valle Pedroso: design, analysis of data and intellectual contribution to the writing of the manuscript. Danilla Icassatti Corazza: design and analysis of data; Carla Andreza de Almeida Andreatto: intellectual contribution to the writing of the manuscript. Thays Martins Vital da Silva: design and analysis of data. José Luiz Riani Costa: design and intellectual contribution to the writing of the manuscript; Ruth Ferreira Santos-Galduróz: design and intellectual contribution to the writing of the manuscript.

\section{Financial support. FAPESP (process 11/03451-8).}

Acknowledgments. The authors are grateful to the Physical Activity and Aging Lab (LAFE), the Programa de Cinesioterapia Funcional e Cognitiva em Idosos com Doença de Alzheimer (PRO-CDA), the Núcleo de Atividade Física e Saúde (NAFES), the Clínica Epiphanio - Rio Claro/SP, the Pró-Reitoria de Extensão Universitária (PROEX-UNESP) the Núcleo Local UNESP-UNATI, the Coordenação de Aperfeiçoamento de Pessoal de Nível Superior (CAPES), the Fundação de Apoio a Pesquisa do Estado de São Paulo (FAPESP), and the Conselho Nacional de Desenvolvimento Científico e Tecnológico (CNPq).

\section{REFERENCES}

1. Freitas EV. Tratado de geriatria e gerontologia. $2^{\mathrm{a}}$ Edição. Rio de Janeiro: Guanabara Koogan; 2006:1750.

2. Manckoundia P, Mourey F, Pfitzenmeyer P, Papaxanthis C. Comparison of motor strategies in sit-to-stand and back-to-sit motions between healthy and Alzheimer's disease elderly subjects. Neuroscience. 2006; 137:385-92.

3. Kato-Narita EM, Nitrini R, Radanovic M. Assessment of balance in mild and moderate stages of Alzheimer's disease. Implications on falls and functional capacity. Arq Neuropsiquiatr. 2011;69(2-A):202-7.

4. Christofoletti G, Oliani MM, Gobbi LTB, Gobbi S, Stella F. Risco de quedas em idosos com Doença de Parkinson e demência de Alzheimer: um estudo transversal. Rev Bras Fisioter. 2006;10(4):429-36.

5. Eggermont LH, Gavett BE, Volkers KM, Blankevoort CG, Scherder EJ, Jefferson AL, et al. Lower-Extremity Function in Cognitively Healthy Aging, Mild Cognitive Impairment, and Alzheimer's Disease. Arch Phys Med Rehabil 2010;91:584-8.

6. Fuentes GP. Funcionalidad y demencia. Rev Hosp Clín Univ Chile. 2008;19:324-9.

7. Lima RA, Freitas CMSM, Smethurst WS, Santos CM, Barros MVG. Nível de atividade física em idosos com doença de Alzheimer medi-

ante aplicação do IPAQ e de pedômetros. Rev Bras Ativ Fis Saúde. 2010;15(3):180-5.

8. APA. Diagnostic and Statistical Manual of Mental Disorders: DSM-IV. 4th ed. Text Revision (DSM-IV-TR) ed. Washington: APA, 2000.

9. Montaño MBMM, Ramos LR. Validade da versão em português da Clinical Dementia Rating (CDR). Rev Saúde Pública. 2005;39.

10. Morris J. The Clinical Dementia Rating (CDR): current version and scoring rules. Neurology. 1993;43:2412-4.

11. Folsten MF, Folsten SE, Mchugh PR. Mini-Mental State: a practical method for grading the cognitive state of patients for the clinician. $J$ Psychiatr Res. 1975;12:198.

12. Brucki SMD, Nitrini $R$, Caramelli P, Bertolucci PHF, Okamoto $\mathbb{H}_{\text {. }}$ Sugestões para o uso do Mini-Exame do Estado Mental no Brasil. Arq Neuropsiquiatr. 2003;61:777-81.

13. Beato RG, Nitrini R, Formigoni AP, Caramelli P. Brazilian version of the Frontal Assessment Battery (FAB). Dement Neuropsychol. 2007;1: 59-65.

14. Dubois B, Slachevsky A, Litvan I, Pillon B. The BAF: A Frontal Assessment Battery at bedside. Neurology. 2000;55:1621-6.

15. Yesavage JA, Brink TL, Lum O, Huang V, Adev M, Leirer VO. Devel- 
opment and validation of a geriatric screening scale. J Psychiatr Res. 1983:17:37-49.

16. Voorrips L, Ravelli A, Dongelmans P, Deurenberg P, Van Staveren W. A physical activity questionnaire for elderly. Med Sci Sports Exerc. 1991;23(8):974-9

17. Pereira FS, Oliveira AM, Diniz BS, Forlenza OV, Yassuda MS. Crosscultural Adaptation, Reliability and Validity of the DAFS-R in a Sample of Brazilian Older Adults. Arch Clin Neuropsychol. 2010;25:335-43.

18. Rikli RE, Jones CJ. Development and validation of a functional fitness test for community-residing older adults. J Aging Phys Activ. 1999;7: 129-61.

19. Osness WH, Adrian M, Clark B, Horger W, Raab D, Wiswell R. Functional Fitness Assessment for Adults Over 60 Years. The American Alliance For Health, Physical Education, Recreation and Dance. Association For Research Administration, Professional Councils, and Societies. Council On Aging and Adult Development. 1990.

20. Berg K, Wood-Dauphinée S, Williams Jl, Fayton L. Measuring balance in the elderly: preliminary development of an instrument. Physiotherapy Canada. 1989;41(6):304-11.

21. Podsiadlo D, Richardson S. The "Timed Up and Go": a test of basic functional mobility for frail elderly persons. J Am Geriatr Soc. 1991;39:142-8.

22. Wells KF, Dillon EK. The Sit and Reach - A test of Back and Leg Flexibility. Research Quarterly. 1952;23:115-118.

23. Laks J, Marinho V, Engeldhart E. Diagnóstico clínico da doença de Alzheimer. In: Bottino CMC, Laks J, Blay SL. Demência e Transtornos Cognitivos em Idosos. 1 ed. Rio de Janeiro: Guanabara Koogan: 2006

24. Pedroso RV, Fraga FJ, Corazza DI, et al. P300 latency and amplitude in Alzheimer's disease: a systematc review. Braz $\mathrm{J}$ Otorhinolaryngol. 2012;78(4):126-32.

25. Christofoletti G, Oliani MM, Bucken-Gobbi LT, Gobbi S, Beinotti F, Stella F. Physical activity attenuates neuropsychiatric disturbances and caregiver burden in patients with dementia. Clinics (Sao Paulo). 2011;66(4):613-8.

26. Tudor-Locke C, Hatano Y, Pangrazi RP, Kang M. Revisiting "how many steps are enough?". Med Sci Sports Exerc. 2008;S537-40.

27. Vital TM, Hernandez SSS, Stein AM, et al. Depressive Symptoms and level of physical activity in patients with Alzheimer's Disease. Geriatr Gerontol Int. 2012;12(4):637-42.

28. Rikli RE, Jones CJ. Development and Validation of Criterion-Referenced Clinically Relevant Fitness Standards for Maintaining Physical Independence in Later Years. The Gerontologist. 2012;0(0):1-13.

29. Monteiro WD, Amorim PRS, Farjalla R, Farinatti PT. Força muscular e características morfológicas de mulheres idosas praticantes de um programa de atividades físicas. Rev Bras Ativ Fis Saúde. 1999; 4(1):20-28.

30. Pedroso RV, Coelho FGM, Santos-Galduróz RF, Costa JLR, Gobbi S, Stella F. Balance, executive functions and falls in elderly with Alzheimer's disease (AD): A longitudinal study. Arch Gerontol Geriatr. 2012;54: 348-51.

31. Coelho FGM, Andrade LP, Pedroso RV, Santos-Galduróz RF, Gobbi S, Costa JLR, Gobbi LTB. Multimodal exercise intervention improves frontal cognitive functions and gait in Alzheimer's disease: A controlled trial. Geriatr Gerontol Int. 2013;13:198-203.

32. Camicioli R, Licis L. Motor Impairment predicts falls in specialized Alzheimer care units. Alzheimer Dis Assoc Disord. 2004;18(4):1-5.

33. Abbot RD, White LR, Ross GW, Masaki KH, Curb JD, Petrovitch, H. Walking and dementia in physically capable elderly men. JAMA. 2014; 292:1447-53.

34. Zanetti O, Frisoni GB, Rozzini L, Biachetti A, Trabucchi M. Validity of direct assessment of functiona I status as a tool for measuring Alzheimer's disease severity. Age and Ageing. 1998;27:615-22.

35. Arcoverde C, Deslandes A, Rangel A, et al. Daily Living in Elderly with Alzheimer's Disease. Arq Neuropsiquiatr 2008;66:323-7. 